\title{
MICROBIAL CONTAMINATION OF THE ENVIRONMENT IN A SPECIALIZED CATTLE FATTENING HOUSE
}

\author{
A. FIŠER, Tatjana FAJNOROVÁ and J. SOKOL \\ Department of Pig Disease Prevention, Animal Breeding and Hygiene, \\ University of Veterinary Science, 61242 Brno, Institute of Animal Hygiene \\ and Veterinary Technology, 91821 Trnava
}

Received Fanuary 30, 1990

\begin{abstract}
Fišer A., Tatjana Fajnorová, J. Sokol: Microbial Contamination of the Environment in a Specialized Cattle Fattening House. Acta vet. Brno, 60, 1991: 71- 77.

Microbial contamination of the environment in bullock calf houses with the animals being housed on slatted litterfree floors corresponded to the range of tolerance proposed for conventional large-scale calf houses when assessing air contamination. In the house for milk-fed calves the air contamination was lowest when evaluating the total number of microbes (t.n.m.) growing on MPA with lactose, while the highest values were found for $\mathrm{L}+$ microbes growing on Endo agar. Considering a zero detection of $\mathrm{L}+$ microbes in the air of the houses, it can be assumed that the house air quality changes with the health condition of the excretors, i.e. the housed bullock-calves.

$\mathrm{L}+$ microbe contamination of indicator site surface areas points out the need for a greater care of drinkers and feed bowls or troughs.
\end{abstract}

Fattening, calves, bullocks, air and surface areas of employed technology, slatted-floor housing

A high concentration of animals concomitant with the currently employed industrial large-scale breeding programmes results in an increasing microbial contamination of the housing environment, the quality and quantity of which is further influenced by the used technology and the type of animal housing.

The present study on the microbial contamination of the air and surface areas of the indicator housing technology sites in our specialized cattle fattening farm should contribute to a deeper understanding of the housing microbism in large-scale farm animal breeding.

\section{Materials and Methods}

A specialized cattle fattening farm at Hladovka, district of Dolní Kubín, can house up to 4,000 bullocks. The bullock calves are housed from the age of 5-12 days, beginning in a milk-feed house in litter-free cubicles with slats at rear parts of the floor. The milk-feed house is divided in sections allowing for the, all in-all out" housing system. Ventilation is forced, isobaric, and with automatic regulation. Slurry is removed by its flowing into a sump, the milk feed mix is rationed into bowls through a hose with a special pistol.

Six to seven weeks later the bullocks are transferred from the milk-feed house to a plant-feed house where they remain until reaching a body mass of $200 \mathrm{~kg}$. This mass attained, the bullocks are transferred to a fattening house. In either of these houses the bullocks are kept in full-slatted floor cubicles. Feeding is secured through a stationary feedline with a combined trough. Ventilation is forced, isobaric, and automatically regulated. Slurry is removed with mechanical scrapers out of the house into a repumping tank.

Between December 3, 1986 and December 15, 1987 the atmospheric microbial contamination was determined ambulantly on 13 occasions using a method of sedimentation with concurrently 
monitoring the temperature and air humidity. Surface area contamination was assessed using detoxified swabs (produced by Imuna Sarišské Michalany) on $100 \mathrm{~cm}^{2}$ of the surface areas of the trough or feed bowl, the drinker, the metal barrier, and the slatted part of the bed. From each of these indicator sites 5 swabs were taken on each of the 13 ambulant measurements, i. e. 20 swabs in one house. The total number of the processed samples was 260, i.e. 65 from one indicator site in each house in the course of the study. The growth media used were MPA with lactose for determining the total number of microbes (t. n. m.), and Endo agar or MPA with brom-thymol blue for the total lactose-positive $(\mathrm{L}+)$ microbes. The results were expressed as the number of microbes in $1 \mathrm{~m}^{3}$ of air after substituting into the formula of Spurný et al. (1961), and as the number of microbes per $100 \mathrm{~cm}^{2}$ of surface area. The data were evaluated statistically calculating the mean, median, the maximum and minimum values, and the correlation coefficient.

The correlation coefficient was calculated as follows:

$$
\text { "cr" }=\frac{n \cdot \sum x y-\left(\sum x\right) \cdot\left(\sum y\right)}{\sqrt{\left[n \cdot \sum x^{2}-\left(\sum x\right)^{2}\right] \cdot\left[n \cdot \sum y^{2}-\left(\sum y\right)^{2}\right]}}
$$

\section{Results}

Microbial contamination of the air is shown in Figs 1 and 2, while that of the indicator site surface areas is seen in Fig. 3. A correlation of the relationships between temperature and air humidity, and airborne microbe counts are presented in Tab. 1 as correlation coefficients " $r$ ".

It is evident from Fig. 1 that on average the t. $n$. m. on MPA with lactose are either below (milk-feed house) or around the lower limit (plant-feed and fattening houses) of the tolerance range recommended by Fišer $(1977,1978)$ for the conventional housing, i. e. $2.2 \times 10^{5}$ microbes in $1 \mathrm{~m}^{3}$ of air. The average hygiene index values for $\mathrm{L}+$ microbes fluctuate around the upper limit of tolerance, and this limit of $5.2 \times 10^{2}$ in $1 \mathrm{~m}^{3}$ is exceeded by its average maxima, and even more by the absolute maximum values, especially in the milk-feed house atmosphere.

Table 1

Correlation between temperature and relative air humidity and the total number of microbes in $1 \mathrm{~m}^{2}$ of the house air as detected on MPA with lactose

\begin{tabular}{|c|c|c|c|c|}
\hline \multirow[b]{2}{*}{ Objects } & \multirow[b]{2}{*}{$\begin{array}{c}\text { Average air } \\
\text { temperature }{ }^{\circ} \mathrm{C}\end{array}$} & \multirow[b]{2}{*}{$\begin{array}{c}\text { Average air } \\
\text { humidity } \%\end{array}$} & \multicolumn{2}{|c|}{ Correlation coefficient " $r$ " } \\
\hline & & & $\begin{array}{c}\text { air temperature } \\
\times \\
\text { Total no. microbes }\end{array}$ & $\begin{array}{c}\text { Relative air humidity } \\
\text { Total no. microbes }\end{array}$ \\
\hline Milk-feed house & 16.1 & 67.5 & +0.167567 & -0.225824 \\
\hline Plant-feed house & 15.9 & 74.1 & +0.229206 & -0.187288 \\
\hline Fattening house & 15.0 & 77.0 & +0.653562 & -0.660233 \\
\hline
\end{tabular}

From Fig. 2 it is apparent that the interval distribution of t. n. m. detected on MPA with lactose is most frequent at about the order of $10^{5}$ for the plant-feed and fattening houses, and at the order of $10^{4}$ for the milk-feed house in $70-80 \%$ of the examined air samples. The interval distribution for $\mathrm{L}+$ microbes varies around the mathematical order of $10^{2}$ for $45-50 \%$ samples while there were zero detections in $18 \%$ samples from the milk-feed house, $13.5 \%$ from the plant-feed house and $9.5 \%$ samples from the fattening house.

Air temperature and humidity as related to t. n. m. detected on MPA with lactose are seen in Tab. 1, and the values are statistically significant only for the 


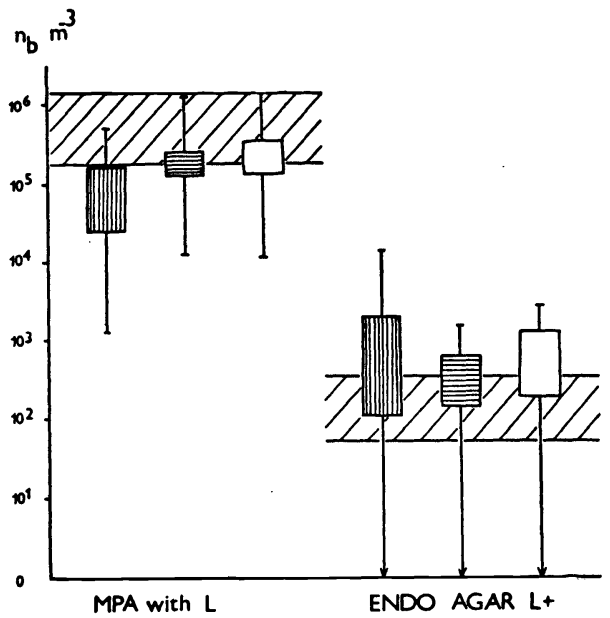

Fig. 1. Microbial contamination of air in bullock-calf fattening houses at VVHD Hladovka.

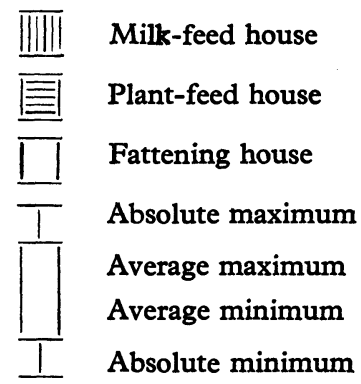

Range of tolerance for microbe concentrations in the air of conventional houses for cattle, pigs and poultry when using a method of sedimentation to detect the microbes: MPA, total number of microbes: $2.2 \times 10^{5}-$ $-1.3 \times 10^{6}$ in $1 \mathrm{~m}^{3}$, i. e. $44-252 \times 10 \mathrm{~cm}^{-2} \times$ $\times \mathrm{mm}^{-1}$. Endo agar, total $\mathrm{L}+$ microbe counts: $7.1 \times 10^{1}-5.2 \times 10^{2}$ in $1 \mathrm{~m}^{3}$ i. e. $0.03-0.1 \times$ $\times 10 \mathrm{~cm}^{-2}$ min. $^{1}$ (Fišer 1977, 1978).

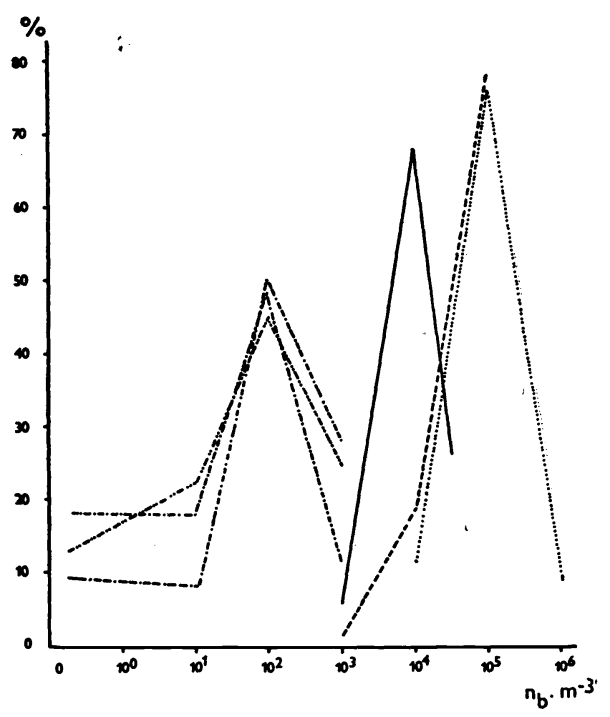

Fig. 2. Relative frequency of t.n.m. on MPA. with lactose, and of $\mathrm{L}+$ microbes on Endo. agar in $1 \mathrm{~m}^{3}$ of air within the range of $0-$ $-10^{6}$ orders of magnitude.

$$
\begin{aligned}
& \text { Milk-feed house } \\
& \text {-.-.-. L+ microbes } \\
& \text { Plant-feed house }-\ldots \text { t.n.m. } \\
& -\ldots-\ldots-\mathrm{L}+\text { microbes } \\
& \text { Fattening house . . . . t.n.m. } \\
& \text { - . . . . L+ microbes }
\end{aligned}
$$

fattening house (" $r$ " $=+0.653562$ and -0.660233 , resp.). The relationship between air temperature and $t$. n. $m$. is positive for all the houses while that between relative air humidity and t. n. m. is negative.

Microbial contaminations of the indicator site surface areas presented in Fig. 3 is lowest for the barriers and highest for the beds in case of $t$. $n$. m. on MPA with lactose. However, $\mathrm{L}+$ microbe contamination is equal for the drinkers and the beds in the milk-feed house, and for the through and the bed in the plant-feed and the fattening houses.

\section{Discussion}

Total microbe numbers on MPA with lactose represent predominantly exogenous microflora invading the house enviroment through antropogenic activity, thus being tolerated in the house environment as a foreign agent in the lowest. 
possible numbers. $\mathrm{L}+$ microbes are regarded as endogenous microflora derived from the animals themselves. This type of microflora is to be envisaged as a facultative pathogen in the housing environment. However, its increase above the usually expected concentrations points, as a rule, to its previous multiplication in the animals' intestine then followed by its intensified excretion into the envi-
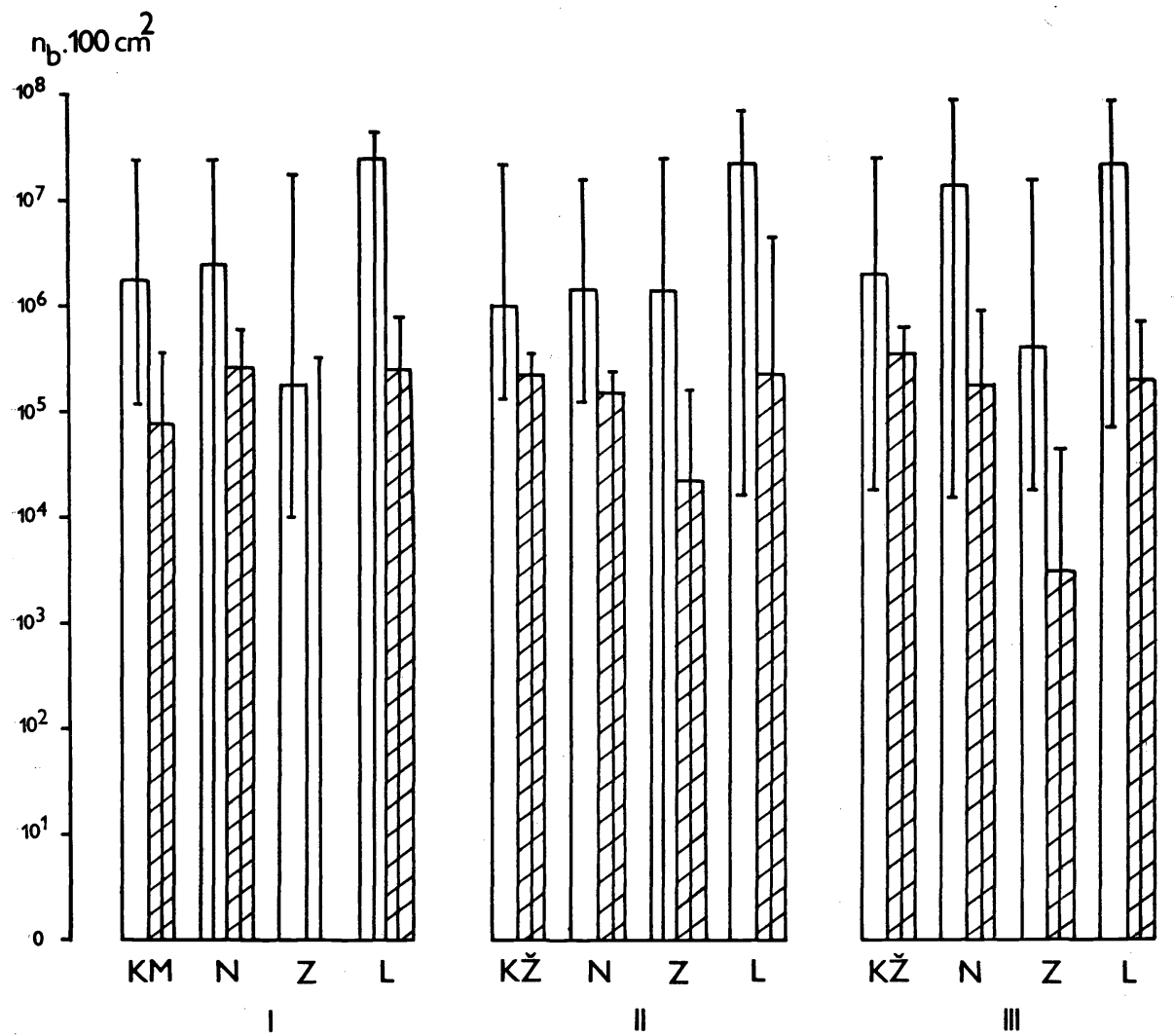

Fig. 3. Microbial contamination of technology indicator sites in fattening houses for bullock-calves at VVHD Hladovka.

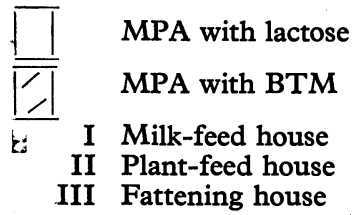

$$
\begin{array}{ll}
\text { KM } & \text { Feed bowl } \\
\text { KŽ } & \text { Feed trough } \\
\text { N } & \text { Drinker } \\
\text { Z } & \text { Barrier } \\
\text { L } & \text { Bed }
\end{array}
$$

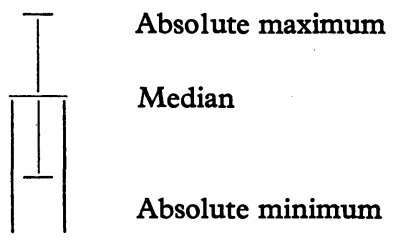

Note: In the milk-feed house the detected median value was zero for indicator site $\mathbf{Z}$ (barrier). 
ronment. Therefore, it serves as an indicator of a potentially progressing disease among the housed animals, which also gives evidence of their health condition.

When assessing air contamination in the house by microbes growing on MPA with lactose and L+microbes growing on MPA with brom-thymol blue, we consider the range of tolerance verified by ourselves for conventional large-scale animal breeding (Fišer 1978, 1977). When considering t. n. m. on MPA with lactose as a criterion, one can regard the atmosphere of the milk-feed house as particularly favourable. On the other hand, however, $\mathrm{L}+$ microbe counts in the calf house atmosphere keep fluctuating around the upper tolerance limit, and this makes the finding from the milk-feed house especially significant. At the same time, when evaluating this hygiene criterion, one should also consider that it was in the milk-feed house where the zero detections were most frequent $(18 \%$ ot all the examinations). This finding points to the transforming quality of the atmosphere within the studied time period of the year, which is most likely connected with the health condition of the excretors, $i$. e. the housed animals. The favourable zero detection of microbes was recorded for the milk-feed house in four successive examinations between 5. 5. 1987 and 30.9. 1987, and in three other examinations on Dec. 3, 1986, March 17, 1987 and Dec. 15, 1987. A reduced infectivity in the milk-feed house can be assumed for over the whole summer period from May to September 1987, thus resulting in a low sickness rate of the housed animals. This view is supported by the results of Duranov (1984), who detected $61.1 \times 10^{3} E$. coli in $1 \mathrm{~m}^{3}$ in the calf house with $E$. coli infected calves, while only $0.42 \times 10^{3} \mathrm{E}$. coli in $1 \mathrm{~m}^{3}$ of air when housing healthy calves. Similar conclusions were reached by Bessarabov et al. (1972), Sedunov et al. (1978) cit. Fedorov et al. (1984) monitoring $E$. coli in chicken house air with intercurrent infectious laryngotracheitis and colibacteriosis, and by Pljashchenko et al. (1988) in pig husbandry practice.

It follows from the correlation analysis that the elevated t. n. m. in $1 \mathrm{~m}^{3}$ of the calf house air resulted from temperature increases with a simultaneous reduction in relative air humidity. On the other hand, reduced temperature with a concurrent increase in relative air humidity results in the houses in a lower t. n. m. detection on MPA with lactose. A similar relationship was arrived at in another study of ours involving groups of calves housed on daily changed litter with the results being significant for temperature (" $r$ " $=+0.5596)$ and relative air humidity (" $r$ " $=-0.3723$ ), as well as for windowless large-scale farrowing houses in pig prefattening hall with dry feed technology and litter-free housing (Fišer 1977). However, these relationships have not been verified for other types of housing involving dairy cows, pigs, poultry, and not even literature data can be regarded as consistent (Beer et al. 1975; Hilliger, Ackermann 1982; Jones et al. 1982; Adrian 1986 - cit. Hilliger et al. 1986). Jones and Webster (1981) have shown that for housing calves of $125-194 \mathrm{~kg}$ the use of the impact method increases the counts of airborne microbes of less than $4.7 \mu \mathrm{m}$ when simultaneously increasing temperature and relative air humidity to $14{ }^{\circ} \mathrm{C}$ and $85 \%$, respectively, while a concurrent decrease in temperature and relative air humidity down to $3{ }^{\circ} \mathrm{C}$ and $58-74 \%$, resp., resulted in reduced microbe numbers of this size.

The results of the microbial contamination control of the housing equipment surface areas pinpoint the high contamination of feed bowls or the throughs and drinkers with $\mathrm{L}+$ microbes at a level comparable to the bed contamination. 
This finding emphasizes the need for a permanent cleanliness and thoroughly performed mechanical cleaning of the contaminated areas of the given indicator sites, where the calves come in direct contact with the facultative pathogenic microflora and good grounds are created for orally acquired infections.

\section{Mikrobiální kontaminace prostředí specializované výkrmny skotu}

Mikrobiální kontaminace prostředí pavilónů mléčné a rostlinné výživy a pavilónu výkrmu telat-býčkủ ustájených bezstelivově na roštech odpovídala při hodnocení vzdušné kontaminace rozsahu tolerance konvenčních velkokapacitních stájí. V pavilónu mléčné výživy byla kontaminace ovzduší c. p. m. rostoucích na MPA s laktózou nejnižší, kontaminace ovzduší $L+$ mikroby rostoucími na Endově agaru byla $\mathbf{v}$ tomto pavilónu nejvyšši. $S$ ohledem na nulové záchyty $\mathrm{L}+$ mikrobů $\mathrm{v}$ ovzduší pavilónů lze usuzovat na měnící se kvalitu stájového. ovzduši v závislosti na zdravotním stavu vylučovatelů, tj. ustájených býčků-telat.

Kontaminace povrchů indikátorových míst $\mathrm{L}+$ mikroby upozorňuje na nutnost zvýšené péče o hygienu napáječek a krmných misek resp. krmných žlabů.

\section{Микробное заражение помещений специализированного откормочника крупного рогатого скота}

Микробная контаминация павильонов молочного и растительного питания и павильона откорма телят-бычков, содержимых на решетках, в ходе оценки воздүшной контаминации соответствовала пределам классических крупных телятников. В павильоне молочного питания контаминация атмосферы с. р. м., растущих на MPA с лактозой была самая низкая, контаминация воздуха микробами $L+$, растүщими на агаре Энда, достигала в данном павильоне самого высокого уровня. Учитывая нулевую задержку микробов L+ в атмосфере павильонов, следует предположить, что причина кроется в меняющемся качестве атмосферы телятника в зависимости от состояния здоровья выделителей, т. е. содержащихся бычков.

Контаминация поверхностей индикаторных точек микробами $\mathrm{L}+$ свидетельствует о необходимости повышенной заботы о гигиене поилок, кормушек или желобов.

\section{References}

BEER, K.-MEHLHORN, G.-ARNOLD, M. M.: Stallkeimflora in Milchviehställen. Ergebnisse quantitativen und qualitativen Untersuchungen. Tierhygiene - Information. Eberswalde - Finow, 7. Jahrgang Sonderheft 1975, 199 p.

DURANOV, V. S.: Vlijanije technologii vedenija životnovodstva na jestěstvennuju resistěntnost životnych. Veterinarija, 7, 1984: 23-24

FEDOROVA, E. P.-JESENKO, J. D.-LUČIN, A. J.-POTREBNJAK, L. L.: Mikroflora vozducha v ptičnike. Veterinarija, $7,198424-25$.

FIŠER, A.: Kritéria pro hodnocení mikrobiálni kontaminace stájového ovzduší. Veterinářství 28, 1978: 200-202

FIŠR, A.: Mikrobiální kontaminace velkokapacitních stájí a možnosti jejího ovlivnění aerosolovou dezinfekcí v prítomnosti zviřat. Habilitation thesis, VSZ Brno, 1977, 176 p. 
HILLIGER, G. H.-AENGST, C.-ADRIAN, U.: Zur Methodik der Erfassung der Keimflroa im Stall. Tierärztliche Umschau, 41, 1986: 851-859

JONES, R. C. - WEBSTER, F. J.: Weather induced changes in airborne bacteria within a calf house. The Veterinary Record 28, 1981: 493-494

PLJAŠ̉̇NKO, S. J. -CHOLCHOVA, J. J. - KUTUZOV, L. S.: Vlijanije technologičeskich faktorov na bakterialnuju obsemeněnost vozducha i zaoblevaemost porosjat - otjomyšel. Veterinarija, 1988, 5: 18-20

SPURNY, K.-JECH, C.-SEDLÁCEK, B.-ŠTORCH, O.: Aerosoly. SNTL, Praha 1961, $342 \mathrm{p}$. 